do BN đến khám, $80 \%$ ĐDV có hỏi lí do BN đến khám và vẫn còn $20 \%$ ĐDV không hỏi, tỷ lệ ĐDV chú ý đến tâm trạng người nhà cũng thấp (chỉ $30 \%$ ). Về hỏi bệnh và hướng dẫn tận tình của ĐDV, tỷ lê ĐDV hỏi bênh, hướng dẫn tân tình đat mức khá tốt. ĐDV hỏi thêm các bệnh có liên quan, $80 \%$ ĐDV giải thích về bệnh cho người nhà và $\mathrm{NB}$ và $100 \%$ ĐDV hướng dẫn người nhà và NB đi làm xét nghiệm. $100 \%$ ĐDV có hướng dẫn sử dụng thuốc cho NB. 53.3\%. ĐDV có giải thích các phương pháp chăm sóc. $65 \%$ ĐDV giải thích cách phòng bệnh cho người nhà và NB. 92,5\% ĐDV có hướng dẫn đến phòng khám tiếp theo. So với nghiên cứu khác, các tiêu chí này có cao hơn [8].

\section{KẾT LUÂN}

- Về Kiến thức đat mức tốt (các tiêu chí đat mức 76,7-100\%) trong đó có những tiêu chí rất cao: $95 \%$ hiểu về sẵn sàng giúp đõ chia sẻ với đồng nghiệp; $97,5 \%$ về bảo vệ danh dự đồng nghiệp, $90 \%$ về người bệnh được quyền biết về bệnh của mình, được giải thích, được lựa chọn kỹ் thuật chăm sóc. Tuy nhiên còn $10 \%$ cho rằng bệnh nhân không được quyền chọn điều dưỡng viên chăm sóc cho mình; 3,3\% không biết nghề điều dưỡng có phù hợp với bản thân không.

- Về Thực hành đạt mức khá tốt (các tiêu chí đat mức 50-100\%) trong đó có những tiêu chí rất cao: $97,5 \%$ thực hiện tốt việc chịu trách nhiệm về hành vi chuyên môn; $100 \%$ trung thực trong sử dụng thuốc và vật tư tiêu hao. Nhưng còn đến $50 \%$ điều dưỡng viên không hỏi thêm người bệnh các bệnh liên quan; chỉ $40 \%$ có giới thiệu tên và nêu lý do tiếp xúc, chỉ $30 \%$ có chú ý tới tâm trạng người nhà người bệnh và $20 \%$ không hỏi lý do người bệnh đến khám

\section{TÀI LIẸU THAM KHẢO}

1. European Nursing Community (2008). Code of Ethics and Conduct for European. Nursing. Protecting the Public and Ensuring patient safety,. P 1-9

2. Australian College of Nursing (2008), Code of Ethics for Nurses in Australia, Nursing and Midwifery Board of Australia, The Australian College of Nursing and The Australia Nursing Federation, ISBN: 978-0-9775108-7-0, 2008.

3. Japanese Nursing Association (2003), The code of ethics for nurses, Full text PDF document. 2003: p. 1-7.

4. College and Association of Registered Nurses of Alberta (CARNA), Nursing Practice Standard, Edmonton, AB T5M 4A6, 2005: p. 1-32.

5. Bộ Y tế (2012). Chuấn năng lực cớ bản của điều dưỡng Việt Nam. Ban hành kèm theo quyết định số: 1352/QĐ-BYT. Tr 1-14

6. Hội Điêuu dưỡng Viêt Nam, Quyết đinh số 20/QĐ-HĐD ngày 10/9/2012 vế chuẩn đạo đức nghể nghiệp của điều dưỡng viên, Hội nghị phát triển nguồn nhân lực điêu dưỡng Việt Nam, 2012: p. 42-49.

7. Bộ Y tế (2017) Quy định việc thành lập, chức nẳng, nhiệm vụ, quyên hạn của Hội đồng đạo đức trong nghiên cứu y sinh hoc. Thông tư 45/2017/TT-BYT (ngày 16/11/2017)

8. Đố Manh Hùng, (2014), Nghiên cứu thực trang nhận thức và thực hành y đức của điều dưỡng viên tại Bệnh viên Nhi Trung ương và kết quả một số biên pháp can thiêpp. Luận văn ThS. Đại học $Y$ Dược Thái Bình.

\title{
ĐÁNH GIÁ HIẾU QUẢ VIRUS VACCINE SỞI VÀ NIMOTUZUMAB GÂY BÊNH CHẾT TẾ BÀO UNG THƯ THEO CON ĐƯỜNG APOPTOSIS GIAI ĐOẠN MUỘN
}

\author{
Hồ Anh Sơn'1, Lê Mạnh Cường², Nguyễn Văn Chuyên'1
}

\section{TÓM TẮT}

Mục tiêu: Đánh giá hiệu quả virus vaccin sởi (MeV) và Nimotuzumab gây chết tế bào ung thư theo con đường apoptosis giai đoạn muộn. Đối tượng và phương pháp: Sử dụng MeV và Nimotuzumab gây chết tế bào ung thư Hep2. Tế bào Hep2 tiếp xúc MeV

${ }^{1}$ Học viện Quân y

²Bệnh viện YHCT Trung ương

Chiu trách nhiệm chính: Hồ Anh Sơn

Email: hoanhsonhp@gmail.com

Ngày nhận bài: 11/11//2020

Ngày phản biên khoa học: 3/12/2020

Ngày duyệt bài: 17/12/2020 và Nimotuzumab được thu thâp ở thời điểm 48 giờ, 72 giờ, 96 giờ để đánh giá bằng kỹ thuật flow cytometry. Kết quả: Tỉ lế tế bào chết theo chương trình giai đoạn muộn ở các nhóm điều trị nhiều hớn có nghĩa thổng kê so với nhóm chứng, thời điểm 96h, kết hợp $\mathrm{MeV}$ và Nimotuzumab gây chết tế bào ung thư apoptosis giai đoạn muộn nhiêu hơn so với dùng đơn. Kết luận: Kết hợp virus vaccine sởi và Nimotuzumab có tác dụng gây chết tế bào Hep2 theo chương trình giai đoạn muộn nhiều hơn dùng đơn virus vaccine sởi hoặc Nimotuzumab.

Tư khóa: Ung thư đâu cổ, virus vaccine sởi, Nimotuzumab, chết theo chương trình

SUMMARY 


\section{EVALUATION THE LATE APOPTOSIS EFFECTS OF VACCINE-STRAIN MEASLES VIRUS AND NIMOTUZUMAB ON CANCER CELLS}

Objectives: This study aims to evaluate of late apoptosis effects of vacine-strain measles virus (MeV) and Nimotuzumab against cancer cells. Materials and methods: MeV and Ninotuzumab were used to induce late apoptosis pathway on Hep2 cancer cells. Hep2 cells treated with $\mathrm{MeV}$ and Nimotuzumab were collected at 48, 72 hours and 96 hours to perform flow cytometry. Results: The proportion of late apoptosis cells in treated groups was significantly higher than control group. MeV and Nimotuzumab combination induced higher rate of late apoptosis cells than thouse in single treatment groups. Conclusion: $\mathrm{MeV}$ and Nimotuzumab combination increases late apoptosis on head and neck cancer Hep2 cells than single MeV or Nimotuzumab treatment.

Keywords: Head and neck squamous-cell carcinoma, measles virus vaccine, Nimotuzumab, apoptosis.

\section{I. ĐẶT VẤN ĐỀ}

Trị liệu bằng virus li giải tế bào ung thư (Oncolytic virus -OLV) dựa trên cơ chế là các OLV có khả năng xâm nhập đặc hiệu vào các tế bào ung thư của khối u, nhân lên, giải phóng và gây li giải tế bào ung thư; kích thích các tế bào ung thư chết theo chương trình; kích thích đáp ứng miễn dịch chống ung thư 1 . Các nghiên cứu đã cho thấy virus vaccine sởi (Measles virus vaccine; $\mathrm{MeV}$ ) là một $\mathrm{OLV}$ an toàn và có khả năng phân giải tế bào ung thư in vitro, in vivo và đang tiến hành các thử nghiệm lâm sàng trên người 2,3 . Nimotuzumab là kháng thể đơn dòng kháng thụ thể EGFR (epidermal growth factor receptor) gắn vào miền ngoại bào của EGFR, ngăn cản hai tiểu phần của EGFR gắn kết đế hoạt hoá nội bào gây cản trở truyền tín hiệu vào trong tế bào có tác dụng chống tăng sinh mạch, kìm hãm tăng sinh tế bào, cảm ứng tế bào chết theo chương trình (apoptosis), làm tế bào tăng nhạy cảm với xạ trị và hóa trị liệu 4.

Tuy nhiên, đến nay chưa có nghiên cứu đánh giá hiệu quả gây chết theo chương trình muộn (late apoptosis) đối với tế bào ung thư biểu mô đâu cổ dưới tác dụng của $\mathrm{MeV}$ và Nimotuzumab. Do đó, chúng tôi đã tiến hành nội dung nghiên cứu này.

\section{II. ĐỐI TƯƠNNG VÀ PHƯƠNG PHÁP NGHIÊN CỨU}

2.1. Đối tượng, vật liệu nghiên cứu. Tế bào ung thư biểu mô vảy đầu cổ người Hep-2 (ATCC CCL-23, laryngeal SCC) được cung cấp bởi công ty ATCC (American Type Culture Collection, P.O. Box 1549, Manassas, VA 20108 USA) được bảo quản tại labo nghiên cứu ung thư của Bộ môn Sinh lý bệnh - Học viện Quân y.

Virus vaccine Sởi (MeV) chủng Edmonton được phân lập, tăng sinh từ vaccine Priorix (GlaxosmithKline, Anh).

Chế phẩm kháng thể đơn dòng Nimotuzumab được nhập khẩu từ $\mathrm{Cu} \mathrm{Ba}$, dưới tên CIMAher, hàm lượng $5 \mathrm{mg} / \mathrm{ml}$.

Bộ kit PE Annexin V Apoptosis Detection kit $(B D)$, môi trường nuôi cấy tế bào và các dụng cụ, hóa chất tiêu hao khác.

\subsection{Phương pháp nghiên cứu}

2.2.1. Thiêt kế nghiên cứu. Nghiên cứu được thiết kế là nghiên cứu thực nghiệm, mô tả cắt ngang có đối chứng.

\subsubsection{Các kỹ thuật sử dụng trong} nghiên cứu

- Kỹ thuật nuôi cấy các dòng tế bào ung thư: Tế bào thận khỉ (Vero cells) được nuôi bằng môi trường M199, phục vụ cho mục đích tăng sinh virus. Tế bào Hep2 được nuôi cấy trên chai nuôi cây tế bào có bổ sung $10 \% \mathrm{FBS}, 1 \%$ Penicillin và Streptomycin, nhiệt độ $37^{\circ} \mathrm{C}, \mathrm{CO}_{2} 5 \%$. Thu tế bào Hep2 bằng Trypsin EDTA, sau đó li tâm để loại bỏ môi trường thu tế bào.

Chuẩn bị tế bào Hep2: Chuẩn độ để được dung dịch tể bào có nồng độ $10^{5}$ tế bào $/ \mathrm{ml}$. Tiến hành cho $3 \mathrm{ml}$ dung dich tế bào trên vào mỗi giếng trên 6 phiến 6 giếng, ủ trong tủ ấm $37^{\circ} \mathrm{C}$, $5 \% \mathrm{CO}_{2}$. Sau 24 giờ, tế bào bám đáy, thay môi trường nuôi cây với từng nhóm như sau: Nhóm chứng: $3 \mathrm{ml}$ môi trường nuôi cấy mới; Nhóm MeV: môi trường nuôi cấy có bổ sung $\mathrm{MeV}$ liều MOI = 1; Nhóm Nimotuzumab: môi trường nuôi cây có bổ sung Nimotuzumab nồng độ $100 \mu \mathrm{g} / \mathrm{ml}$; Nhóm MeV+Nimotuzumab: môi trường nuôi cấy có bổ sung $\mathrm{MeV}$ liều $\mathrm{MOI}=1$ và Nimotuzumab nồng độ $100 \mu \mathrm{g} / \mathrm{ml}$.

Sau 48, 72 và 96 giờ sau tiếp xúc với MeV và Nimotuzumab, tiến hành thu tế bào để chạy flow cytometry đo tế bào chết apoptossis sớm.

Kỹ thuật phân tích tế bào dòng chảy đánh giá tế bào chết theo chương trình (apoptois): sứ dụng kháng thể kháng Annexin $\mathrm{V}$ gắn với tác nhân phát huỳnh quang $P E$ và chất nhuộm nhân tế bào 7AAD (có dải sóng kích thích/phát xa trùng với PerCP-Cy5-5-A). Tế bào được xử lý và nhuộm theo quy trình và hóa chất của bộ kit $\mathrm{PE}$ Annexin V Apoptosis Detection kit (BD).

Đánh giá tî lệ tế bào chết apoptosis sớm trên hê thống FACS CANTO 2 (BD): xác định quần thể tế bào cần đánh giá, xác định vùng giá trị huỳnh quang ( $P E$ và PerCP) âm tính, xác định tỉ lệ tế bào chết apoptosis/hoại tử. Tín hiệu PE cho thấy 
sư biểu hiên của Anexin V. Tín hiêu của PerCPCy5-5A cho thấy sự biểu hiện của 7AAD. Số tế bào chết apoptosis muộn sẽ là tổng của vùng Q2.

2.3. Xử lý thống kê: So sánh trung bình của 2 nhóm độc lập bằng $\mathrm{T}$-test, so sánh trung bình của 3 nhóm bằng phân tích phương sai ANOVA. Số liệu được xử lý bằng phần mềm SPSS 20.0 và GraphPad Prism 6. Sự khác biệt có ý nghĩa thống kê khi $p<0,05$.

\section{KẾT QUẢ NGHIÊN CỨU}

3.1. Tế bào Hep2 chết apoptosis muộn ở thời điểm 48 giờ

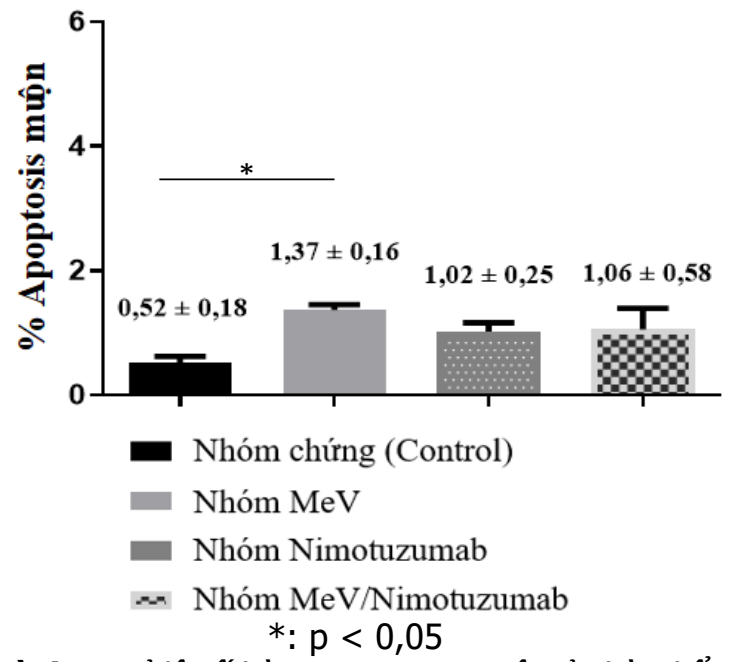

Hinh 1. Ti lệ tê bào apoptosis muộn ở thời điểm 48 giờ sau điều trị băng MeV và Nimotuzumab

Tại thời điểm $48 \mathrm{~h}$, kết quả cho thây tỷ lệ tế bào chết apoptosis muộn ở nhóm điều trị MeV cao hơn nhóm chứng $(p<0,05)$, các nhóm điều trị khác chưa thấy rõ sự khác biệt (hình 1).

3.2.Tế bào Hep2 chết apoptosis muộn ở thời điểm 72 giờ

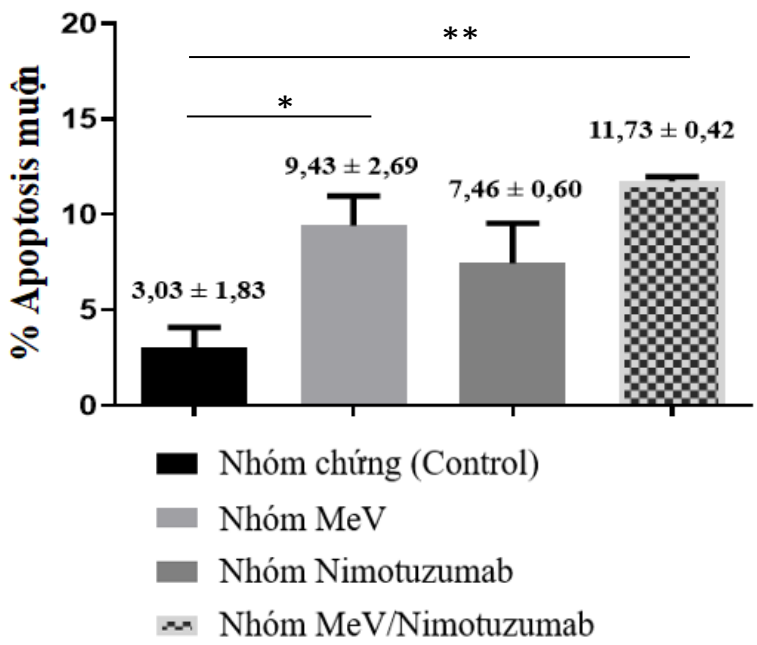

$*: \mathrm{p}<0,05 ; * *$ : $<<0,01 ; * * *$ : $\mathrm{p}<0,001$

Hinh 2. Kết quả chạy flow cytometry tế bào Hep2 ở thời điểm 72 giờ sau điều trị bằng MeV và Nimotuzumab

ở thời điểm 72 giờ sau điều trị, tỉ lê tế bào chết apoptosis giai đoạn muộn ở các nhóm điều trị bằng $\mathrm{MeV}$ và Nimotuzumab cao hơn có ý nghĩa thống kê $(p<0,05)$ so với nhóm chứng với $\mathrm{p}_{\text {(Mev-Control) }}=0,012 ; \mathrm{p}$ (Nimotuzumab-Control) $=0,056 ; \mathrm{p}$ $($ MeV+Nimotuzumab-Control) $=0,002$. Nhóm phối hợp MeV và Nimotuzumab có tî lệ tế bào apoptosis giai đoạn muộn cao hơn so với hai nhóm điều trị đơn; nhóm điều trị bằng $\mathrm{MeV}$ có tỷ lệ tế bào apoptosis giai đoạn muộn cao hơn so với nhóm điêu trị bằng Nimotuzumab; tuy nhiên sự khác biệt ở các nhóm được điều trị bằng $\mathrm{MeV}$ và Nimotuzumab này không có ý nghĩa thống kê với $\mathrm{p}$ (MeV+Nimotuzumab-MeV) $=0,280 ; \quad \mathrm{p}_{(\text {MeV+Nimotuzumab- }}$ Nimotuzumab) $=0,064 ; p$ (MeV- Nimotuzumab) $=0,352)$ (hình 2).

3.3. Tế bào Hep2 chết apoptosis muộn ở thời điểm 96 giờ

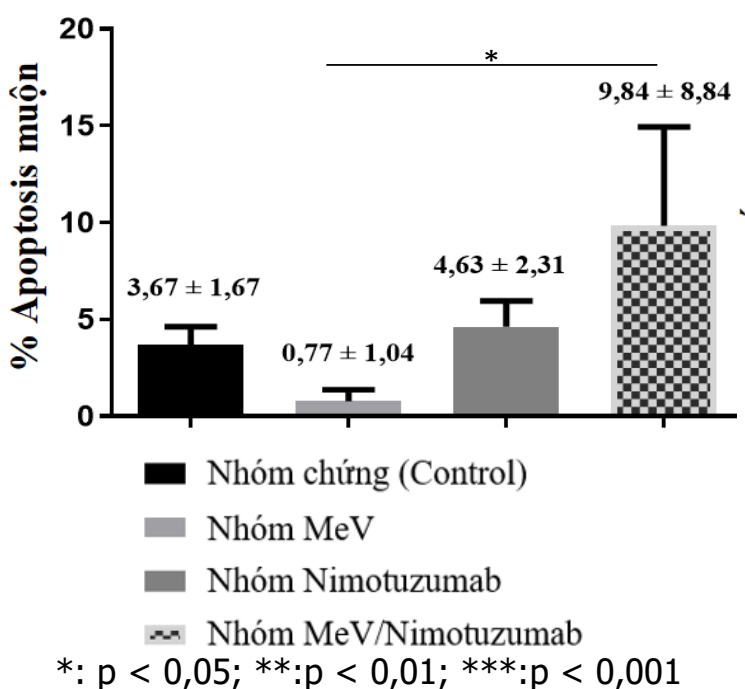

Hinh 3. Kêt quả chạy flow cytometry tế bào Hep2 ở thời điểm 96 giờ sau điều trị bằng MeV và Nimotuzumab

ở thời điểm 96 giờ, tỉ lệ tế bào chết apoptosis giai đoạn muộn nhóm Nimo và nhóm phối hợp cao hớn so với nhóm $\mathrm{MeV}$ và nhóm chứng (Nimotuzumab là 4,63 $\pm 2,31 ; \mathrm{MeV}+$ Nimotuzumab là $9,84 \pm 8,84$; MeV là $0,77 \pm$ $1,04$; so với nhóm chứng là $3,67 \pm 1,67)$. Nhóm phối hợp MeV và Nimotuzumab có tỉ lệ tế bào apoptosis giai đoạn muộn cao hơn so với hai nhóm điều trị đơn; sự khác biệt có ý nghĩa thống kê với $p(\mathrm{MeV} /$ Nimotuzumab $-\mathrm{MeV})=0,045$ (hình 3 , hình 4). 


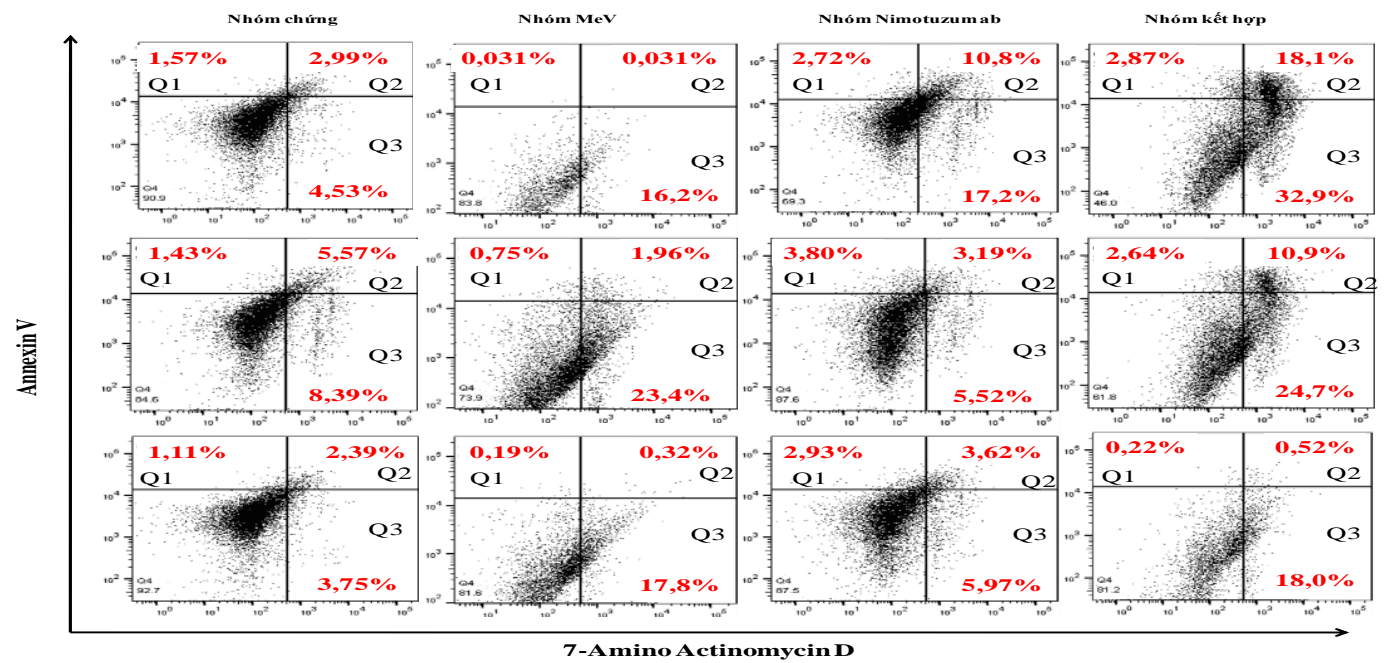

Hình 4. Kêt quả chạy flow cytometry tế bào Hep2 ở thời điểm 96 giờ sau điều trị bằng MeV và Nimotuzumab

Q1 là vùng tế bào apoptosis giai đoạn sớm; Q2 là vùng tế bào apoptosis giai đoạn muộn; Q3 là vùng tế bào hoại tử

\subsection{Tỷ lệ tế bào chết apoptosis muộn ở các nhóm nghiên cứu theo thời gian}
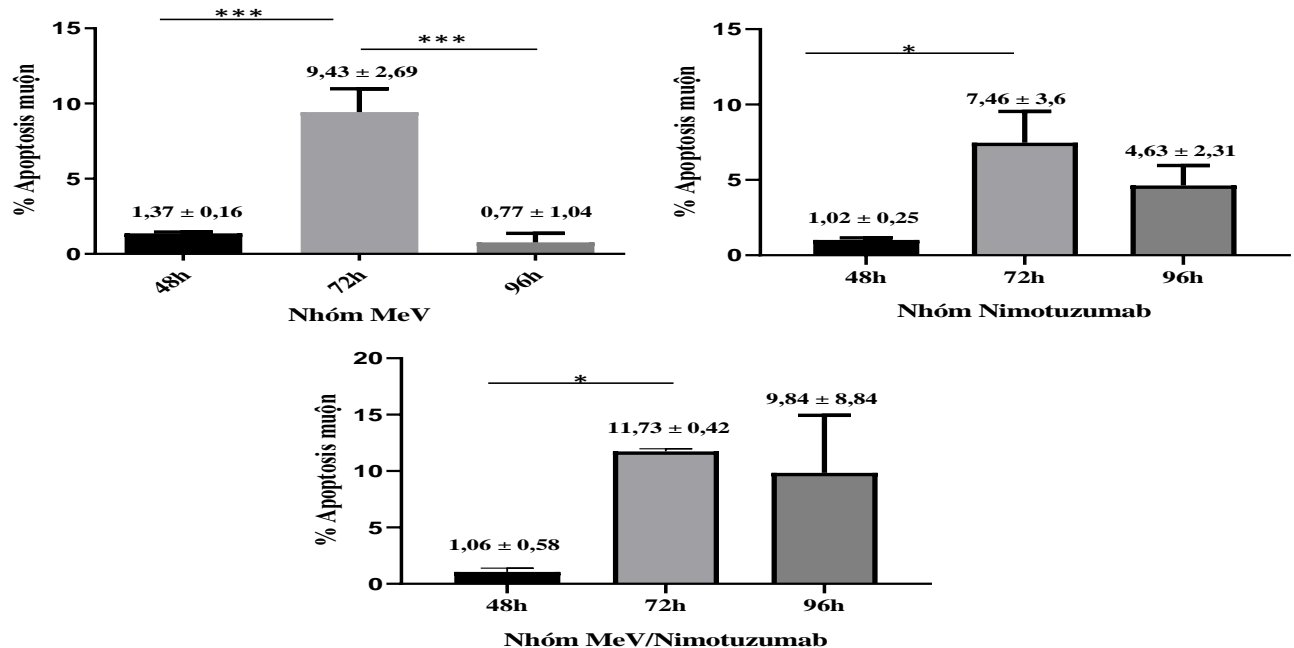

Hình 5. So sánh tỉ lệ tế bào apoptosis muộn theo thời gian điều trị bằng MeV và Nimotuzumab

$$
* \text { : } p<0,05 ; * *: p<0,01 ; * * *: p<0,001 \text {. }
$$

Khi so sánh kết quả tỉ lệ tế bào apoptosis muộn ở các mẫu theo thời gian điều trị bằng MeV và Nimotuzumab cho thấy: tỉ lệ tế bào chết apoptosis muộn đạt mức cao nhất ở thời điểm 72 giờ, sự khác biệt này có ý nghĩa thống kê $(p<$ $0,05)$; kết quả nhóm điều trị bằng $\mathrm{MeV}$ (48 giờ là $1,37 \pm 0,16 ; 72$ giờ là $9,43 \pm 2,69 ; 96$ giờ là $0,77 \pm 1,04$ với $\mathrm{p}_{\text {(72 giờ-48 giờ) }}=0,001 ; \mathrm{p}_{\text {(72 giơ-96 giơ) }}$ $=0,001 ; p_{(48}$ giờ-96 giờ) $\left.=0,677\right) ;$ kết quả ở các nhóm điều trị bằng Nimotuzumab (48 giờ là 1,02 $\pm 0,25 ; 72$ giờ là $7,46 \pm 3,6 ; 96$ giờ là $4,63 \pm$ 2,11 với $\mathrm{p}$ (72 giờ-48 giờ) $=0,019 ; \mathrm{p}$ (72 giờ-96 giờ) $=$ 0,124; $\mathrm{p}$ (48 giờ-96 giờ) = 0,21); kết quả ở các nhóm điều trị kết hợp MeV và Nimotuzumab (48 giờ là $1,06 \pm 0,58 ; 72$ giờ là $11,37 \pm 0,42 ; 96$ giờ là $9,84 \pm 8,84$ với $\mathrm{p}$ (72 giờ-48 giờ) $=0,043 ; \mathrm{p}$ (72 giờ-96 giờ) $=0,666 ; p$ (48 giò̀-96 giò) $=0,080) ;($ hình 5).

\section{BÀN LUÂ̂N}

Kết quả đã chứng minh MeV và Nimotuzumab có khả năng ly giải tế bào Hep2 in vitro qua trung gian kích hoạt con đường tế bào chết apoptosis ở tất cả các thời điểm nghiên cứu. Những kết quả tỉ lệ tế bào chết theo chương trình và tế bào hoại tử bằng phương pháp flow cytometry hoàn toàn phù hợp với hình ảnh 
chúng tôi quan sát sự thay đổi số lượng và hình thái của tế bào Hep2 điều trị bằng $\mathrm{MeV}$ và Nimotuzumab trên đĩa nuôi cấy bằng kính hiển vi thường. Điều này cho thấy: Quá trình apoptosis sớm diễn ra ở các nhóm điều trị bằng $\mathrm{MeV}$ rõ rêt từ thời điểm 48 giờ, tới thời điểm 72 giờ thì quá trình apoptosis sớm giảm, quá trình apoptosis muộn tăng lên, tới thời điểm 96 giờ thì quá trình hoại tử tế bào tăng lên rõ rêt. Quá trình apoptosis diễn ra ở nhóm điều trị bằng Nimotuzumab diễn ra chậm hơn so với nhóm MeV: tại thời điểm 48 giờ tỷ lê tế bào apoptosis ít, tại thời điểm 72 giờ tỷ lệ tế bào apoptosis sớm và muộn tăng rõ, tại thời điểm 96 giờ thì tỷ lệ apoptosis sớm đạt mức cao nhất và cao hơn nhóm điều trị bằng MeV.

$\mathrm{MeV}$ chủng Edmonston sử dung thu cảm thể đặc hiệu CD46 để xâm nhập vào tế bào đích. CD46 không chỉ là nơi MeV gắn và xâm nhập vào tế bào, mà còn thúc đẩy quá trình virus tạo ra sự hợp bào giữa tế bào bi nhiếm virus và các tế bào ung thư lân cận 4. Như vậy, ở các tế bào bình thường có mật độ CD46 thấp, MeV có khả năng lây nhiễm tạo hợp bào là không đáng kể và không có khả năng phát tán virus. Ở các tế bào ung thư có biểu hiện thụ thể CD46 cao, lây nhiễm $\mathrm{MeV}$ dẫn đến phản ứng hợp bào mạnh mẽ. Nghiên cứu gần đây trên 38 bệnh nhân đa u tủy thì mức độ biểu hiện CD46 ở các tế bào u tủy cao hơn nhiêu (49.130/tế bào) so với các tế bào tủy xương bình thường (7.340/tế bào). Hiệu quả phá hủy tế bào manh mẽ của sự hợp bào trên phạm vi rộng lớn đã được quan sát thấy trong các tế bào u tủy sau khi điêu trị bằng virus sởi, hầu như không xảy ra ở các tế bào tủy xương bình thường 5 .

\section{KẾT LUÂN}

Nghiên cứu của chúng tôi cho thây khả năng gây tăng khả năng chết theo chương trình giai đoạn muộn trên tế bào ung thư đầu cổ của virus vaccine sởi và Nimotuzumab in vitro. Việc kết hợp MeV và Nimotuzumab gây chết theo chương trình giai đoạn muộn làm tăng có ý nghĩa thống kê số lượng tế bào chết apoptosis muộn so với điều trị đơn MeV hoặc Nimotuzumab trên dòng tế bào Hep2.

\section{TÀl LIỆ THAM KHẢO}

1. Vigneswaran N., Williams M.D. (2014). Epidemiologic trends in head and neck cancer and aids in diagnosis. Oral Maxillofac Surg Clin North Am., 26(2):123-141.

2. Prestwich R.J., Harrington K.J., Pandha H.S., et al. (2008). Oncolytic viruses: a novel form of immunotherapy. Expert Rev Anticancer Ther., 8(10):1581-1588.

3. Miyamoto $S_{.,}$Inoue $H_{.}$, Nakamura $T_{\text {., }}$ et al. (2012). Coxsackievirus B3 is an oncolytic virus with immunostimulatory properties that is active against lung adenocarcinoma. Cancer Res., 72(10): 2609-2621.

4. Msaouel P., Opyrchal M., Domingo Musibay E., et al. (2013). Oncolytic measles virus strains as novel anticancer agents. Expert Opin Biol Ther., 13(4):483-502.

5. Ong H.T., Timm M.M., Greipp P.R., et al. (2006). Oncolytic measles virus targets high CD46 expression on multiple myeloma cells. Exp Hematol., 34(6):713-720.

\section{NGHIÊN CỨU MỐI LIÊN QUAN GIỮA LÂM SÀNG VÀ HÌNH ẢNH CLVT Sọ NÃO ở BÊ̂NH NHÂN ĐộT QUỴ NÃO CẤP}

\section{TÓM TẮT}

Muc tiêu: Nghiên cứu mối liên quan giữa lâm sàng và hình ảnh CLVT sọ não ở bệnh nhân đột quy. não cấp. Đối tượng và phương pháp: NC tiến cứu, mô tả cắt ngang 120 bệnh nhân được chẩn đoán lâm sàng là đột quy não cấp và được chụp chụp CLVT sọ não không tiêm thuốc cản quang tại Bệnh viện ĐKKV

\footnotetext{
*Trương $Đ H$ Y khoa Pham Ngoc Thach, **BV đa khoa Nhơn Trach, Đồng Nai Chịu trách nhiệm chính: Đặng Vĩnh Hiệp Email: hiepdv@pnt.edu.vn

Ngày nhận bài: 30/10/2020

Ngày phản biên khoa hoc: 25/11/2020

Ngày duyệt bài: 16/12/2020
}

\section{Đặng Vĩnh Hiệp*, Đỗ Thị Nguyên**}

Long Thành từ từ tháng 05 năm 2017 đến tháng 12 năm 2017. Tiến hành thu thập các số liệu về lâm sàng, và các đặc điểm hình ảnh trên phim CLVT sọ não không tiêm thuốc theo mẫu bênh án có sẵn. Phân tích số liệu theo phần mềm thống kê thích hợp và đưa ra kết quả theo mục tiêu nghiên cứu. Kết quả và kết luâan: Liên quan một số yếu tố nguy cơ với loại tổn thương (nhồi máu não, xuất huyết não): Tuổi trung bình của đối tượng nhối máu não $(68,0 \pm 13,5)$ cao hơn xuất huyết não $(60,6 \pm 17,1)$ có ý nghĩa thống kê $(p<0,05)$. Tỉ lệ nhồi máu não và tỉ lệ xuất huyết não không phụ thuốc vào giới và các yếu tố nguy cơ khác như: tăng huyểt áp, đái tháo đường, bênh lý tim mạch $\left(X^{2}, p>0,05\right)$. Liên quan giữa đặc điểm lâm sàng với loại tổn thương: Xuất huyết não có tỉ lệ rối loạn vận động $(80,0 \%)$ cao hơn nhồi máu não $(41,5 \%)\left(\dot{X}^{2}, p<\right.$ 